\title{
PEMBELAJARAN FISIKA DENGAN MODEL BRAIN BASED LEARNING (BBL): DAMPAK PADA KETERAMPILAN BERPIKIR KRITIS
}

\section{PHYSICS LEARNING WITH BRAIN BASED LEARNING (BBL) MODEL: IMPACT ON SKILLS CRITICAL THINKING SKILLS}

\author{
Henda Diani ${ }^{1}$ Irwandani $^{2}$, Dwi Fujiani ${ }^{3}$ \\ ${ }^{1,2}$ Prodi Pendidikan Fisika Fakultas Tarbiyah dan Keguruan Universitas Islam Negeri Raden Intan \\ Lampung \\ ${ }^{3}$ Prodi Pendidikan Biologi Fakultas Tarbiyah dan Keguruan Institut Agama Islam Negeri Kerinci, Jambi \\ E-mail: 16hendadiani@gmail.com
}

Diterima: 9 Agustus 2019. Disetujui: 15 November 2019. Dipublikasikan: 29 November 2019

\begin{abstract}
This research aims to find out if there is influenceof using Brain Based Learningmodel towards students' critical thinking skills of class XI SMAMuhammadiyah 2 Bandar Lampung.This study is quasy experimental research. The population in this study isclass XI SMA Muhammadiyah 2 Bandar Lampung, sampling techniques using purposive sampling, where the class is a class experiment XI IPA 1 and XI IPA 2 is a class of control, this researcheffort fluid static. The instrument used to test students' critical thinking skills isessay. Beside on the research and data management t-test analysis on a significant level $=0.05$ obtained $t_{\text {arithmetic }}>t_{\text {table }}$ is $3,81>1,66$ mean $H_{0}$ rejected. The results of data analysis showed that the Brain Based Learning model influenced the students' critical thinking skillsof class XI SMA Muhammadiyah 2 Bandar Lampung
\end{abstract}

Keywords: quasy experiment, brain based learning, critical thinking skills

Abstrak: Penelitian ini bertujuan untuk mengetahui pengaruh model pembelajaran Brain Based Learning terhadap keterampilanberpikir kritis siswa kelas XI SMAMuhammadiyah 2 Bandar lampung. Penelitian ini merupakan jenis penelitian Quasy experiment, populasi dalam penelitian ini adalah kelas XI SMAMuhammadiyah 2 Bandar Lampung, teknik pengambilan sampel menggunakan purposive sampling, dimana kelas XI IPA I merupakan kelas eksperimen dan kelas XI IPA 2 merupakan kelas kontrol, materi pada penelitianiniyaitufluidastatis. Instrumen yang digunakan untuk keterampilan berpikir kritis adalah tes uraian.Berdasarkan hasil penelitian dan pengelolaan data analisis uji-t pada taraf signifikan $=0,05$ diperoleh $\mathrm{t}_{\text {hitung }}>\mathrm{t}_{\text {tabel }}$ yaitu 3,81>1,66berarti $\mathrm{H}_{0}$ ditolak. Hasil analisis data menunjukan bahwa model pembelajaran Brain Based Learning berpengaruh terhadap keterampilanberpikir kritis siswakelas XI SMAMuhammadiyah 2 Bandar Lampung.

(C) 2019 Unit Riset dan Publikasi Ilmiah FTK UIN Raden Intan Lampung

Kata Kunci: quasy eksperimen, brain based learning, keterampilan berpikir kritis

\section{PENDAHULUAN}

Pendidikan merupakan salah satu aspek yang sangat penting dalam kehidupan manusia. Bahkan ada pepatah yang mengatakan maju mundurnya suatu negara tergantung pada pendidikan yang diberikan kepada masyarakatnya(Isro'i \& Ghufron, 2015). Maka dari itu pendidikan menjadi sarana utama yang perlu dikelola, secara sistematis dan konsisten (Ihsan, 2011). Pendidikan ini tidak terlepas dari proses belajar dan mengajar(Diani, Latifah, Anggraeni, \& Fujiani, 2018).

Berdasarkan hasil observasi peneliti di SMA Muhammadiyah 2 Bandar Lampung, proses pembelajaran fisika 
masih bersifat teacher centered. Hal ini ditandai dengan proses pembelajaran yang lebih banyak didominasi guru, sementara siswa lebih pasif. Selain itu keterampilan berpikir kritis siswa masih rendah.Hal ini ditunjukkan saat siswa menyelesaikan soal fisika yang diberikan guru belum disertai pemahaman yang mendalam terkait soal tersebut. Maka dari itu, perlu kiranya menciptakan suatu lingkungan belajar fisika yang bertujuan untuk membantu melatih pola pikir siswa agar dapat memecahkan masalah dengan kritis, logis dan tepat.

Pembelajaran yang efektif adalah pembelajaran yang mampu menyeimbangkan seluruh potensi berpikir siswa(Lestari, 2014). Kemampuan berpikir kritis merupakan bagian dari kemampuan berpikir matematis yang perlu dimiliki oleh setiap siswa dalam menghadapi berbagai permasalahan. Menurut Anderson (dalam Lestari, 2014)bila berpikir kritis dikembangkan, seseorang akan cenderung untuk mencari kebenaran, berpikir divergen (terbuka dan toleran terhadap ide-ide baru), dapat menganalisis masalah dengan baik, berpikir secara sistematis, penuh rasa ingin tahu, dewasa dalam berpikir, dan dapat berpikir secara mandiri. Kemampuan berfikir kritis dipengaruhi oleh banyak faktor (Saregar et al., 2018). salah satunya itu dopemgaruhu oleh otak. Otak merupakan pusat dari semua aktivitas termasuk berpikir.

Salah satu model pembelajaran yang memperhatikan dan mengembangkan potensi otak untuk dapat mengembangkan keterampilan berpikir kritis siswa sehingga dapat menemukan langkahlangkah yang tepat untuk memecahkan permasalahan adalah menggunakan Brain Based Learning (BBL).

\section{LANDASAN TEORI}

\section{Model Brain Based Learning}

Menurut Given, Model BBL (Brain Based Learning). bertujuan untuk mengembangkan lima sistem pembelajaran alamiah otak yang dapat mengembangkan potensi otak dengan maksimal. Kelima sistem pembelajran tersebut adalah sistem pembelajaran emosional, sosial, kognitif, fisik, dan reflektif. Kelima pembelajaran tersebut saling mempengaruhi dan tidak dapat berdiri sendiri(Mustiada, Agung, \& Antari, 2014).

Jensen menyatakan bahwa pembelajaran berbasis kemampuan otak mempertimbangkan apa yang sifatnya alami bagi otak dan bagaimana otak dipengaruhi oleh lingkungan dan pengalaman(Nur, 2016). Selanjutnya menurut Jensen, ada tiga strategi utama yang dapat dikembangkan dalam implementasi BBL ini yakni: (1) menciptakan lingkungan belajar yang menantang kemampuan berpikir siswa; (2) menciptakan lingkungan pembelajaran yang menyenangkan; dan (3) menciptakan situasi pembelajaran yang aktif dan bermakna (Laksmi, Sujana, \& Suryaabadi, 2014). Ada tujuh tahap dalam pelaksanaan model BBL yaitu: 1) tahap pra-pemaparan; 2) tahap persiapan; 3) tahap inisiasi dan akuisisi; 4) tahap elaborasi; 5) tahap inkubasi dan memasukkan memori; 6) tahap verifikasi dan pengecekan keyakinan; dan 7)tahap pengayaan dan integrasi.

\section{KeterampilanBerpikirKritis}

Berpikir kritis didefinisikan oleh Ennissebagai sebuah pemikiran yang masuk akal dan reflektif yang berfokus untuk memutuskan apa yang harus dipercaya atau dilakukan (Pratiwi \& Muslim, 2016). Menurut York, Gibson \& Ranking (dalam Wati \& Fatimah, 2016) berpikir kritis merupakan indicator kesuksesan dalam pembelajaran. Menurut Jones et al, (dalam Pratiwi \& Muslim, 2016). Keterampilan berpikir kritis sebagai dasar seseorang untuk mengembangkan kemampuan berpikir masa depan sehingga mampu 
menganalisis, mendeteksi dan mengevaluasi kemungkinan yang terjadi dimasa depan. Selain itu, menurut Kuswana (dalam Pratiwi \& Muslim, 2016) menyebutkan bahwa pengembangan keterampilan berpikir merupakan dasar untuk membangun pengetahuan, sikap dan keterampilan motorik seseorang.

\section{METODE PENELITIAN}

Penelitianinimenggunakan Quasi Eksperiment Design. Penelitian ini dilakukan di SMA Muhammadiyah 2 Bandar Lampung Tahun Ajaran 2016/2017. Desain penelitian yang digunakan dalam penelitian ini yaitu Nonequivalent Control Group Design, dengan desainnya dapatdilihat pada tabel 1 berikut.

Tabel 1. Desain Penelitian

$\begin{array}{llll}\text { Kelas eksperimen } & \mathrm{O}_{1} & \mathrm{X} & \mathrm{O}_{2} \\ \text { Kelas kontrol } & \mathrm{O}_{3} & & \mathrm{O}_{4}\end{array}$

Pada penelitian ini terdapat dua macam variabel yaitu: variabel bebas dan variabel terikat.

1. Variabel bebas dalam penelitian ini adalah model pembelajaran Brain Based Learning (BBL).

2. Variabel terikat dalam penelitian ini adalah keterampilan berpikir kritis siswa siswa.

\section{Populasi, Sampel dan Teknik pengambilan Sampel}

1. Populasi

Populasi pada penelitian ini adalah seluruh siswa kelas XI SMA Muhammadiyah 2 Bandar Lampung Tahun Ajaran 2016/2017.

2. Sampel

Sampel pada penelitian ini terdiri dari dua kelas yaitu kelas XI IPA 1 sebagai kelas eksperimen dan kelas XI IPA 2 sebagai kelas kontrol.

3. Teknik PengambilanSampel
Teknik pengambilan sampel yang digunakan pada penelitian ini adalah teknik pengambilan Sampling Purposive atau sampel bertujuan.

\section{Teknik Pengumpulan Data}

Untuk memperoleh data dalam penelitian, peneliti menggunakan beberapa metode pengumpulan data sebagai berikut.

1. Tes

2. Wawancara

3. Observasi

\section{Uji CobaInstrumen}

\section{Uji Validitas}

Rumus yang digunakan untuk menghitung validitas tes dalam penelitian ini adalah rumus kolerasi Karl Pearson sebagai berikut(Sundayana, 2014).

$r_{x y}=\frac{n \sum X Y-\left(\sum X\right)\left(\sum Y\right)}{\sqrt{\left\{n \sum X^{2}-\left(\sum X\right)^{2}\right\}\left\{n \sum Y^{2}-\left(\sum Y\right)^{2}\right\}}}$

2. Tingkat Kesukaran

3. DayaPembeda

$$
T K=\frac{S A+S B}{I A+I B}
$$

4. Uji Reliabilitas

$$
\mathrm{DP}=\frac{\mathrm{SA}-\mathrm{SB}}{\mathrm{IA}}
$$

Perhitungan uji reliabilitas dengan menggunakan rumus Alpha sebagai berikut (Arikunto, 2014).

$\mathrm{r}_{11}=\left(\frac{k}{k-1}\right)\left(1-\frac{\Sigma \sigma_{\mathrm{i}}^{2}}{{\sigma_{\mathrm{i}}}^{2}}\right)$

keterangan:

$\mathrm{r}_{11}=$ Reliabilitas instrumen

$\mathrm{n} \quad=$ Banyaknya butir pertanyaan

$\Sigma \sigma_{i}^{2}=$ Jumlah varians skor dari tiap-tiap butir item

$\sigma_{i}^{2}=$ Varians total

\section{Pengambilan Kesimpulan ButirSoal}

Berdasarkan hasil perhitungan dan analisis uji validitas, tingkat kesukaran, daya beda dan uji reliabilitas butir soal keterampilan berpikir kritis. Soal yang digunakan dalam penelitian ini sebagai tes keterampilan berpikir kritis fisika di Kelas Eksperimen dan Kelas Kontrol adalah soal-soal yang memenuhi kriteria. Berdasarkan hasil perhitungan, diketahui 
bahwa dari 20 soal uraian terdapat 10 soal yang dinyatakan diterima dan 10 soal yang dinyatakan ditolak. Selanjutnya, soal yang dinyatakan diterima digunakan sebagai instrument tes berjumlah 10 soal pretest dan postest yang digunakan dalam penelitian ini.

\section{Teknik Analisis Data}

Setelah data terkumpul, data di analisis dengan menggunakan langkahlangkah sebagai berikut:

\section{Uji Normalitas dengan Uji Liliefors}

Uji normalitas dilakukan untuk mengetahui apakah sampel yang diambil dalam penelitian berdistribusi normal atau tidak. Uji normalitas populasi harus penuhi sebagai syarat untuk menentukan perhitungan yang akan dilakukan pada uji hipotesis berikutnya. Uji normalitas yang digunakan pada penelitian ini ada uji liliefors. Dengan langkah-langkah sebagai berikut (Sundayana, 2014).

1. Menghitung nilai rata-rata dan simpangan bakunya

2. Menyusun data dari yang terkecil sampai data terbesar

3. Mengubah nilai $x$ pada nilai $z$

4. Menghitung luas $z$ dengan menggunakan tabel z

5. Menentukan nilai proporsi data yang lebih kecil atau sama dengan data tersebut.

6. Menentukan selisih luas $\mathrm{z}$ dengan nilai proporsi

7. Menentukan luas maksimum (L maks) dari langkah $\mathrm{f}$

8. Menentukan luas tabel liliefors ( $\left.\mathrm{L}_{\text {tabel }}\right)$; $\mathrm{L}_{\text {tabel }}=\mathrm{L}(\mathrm{n}-1)$

9. Kriteria kenormalan: jika $\mathrm{L}_{\text {maks }}<\mathrm{L}_{\text {tabel }}$ maka dapat berdistribusi normal.

10. Kriteria pengujian adalah sebagai berikut :

a. Tolak : Ho jika Lo $>$ Lt

b. Terima : Ho jika Lo $\geq$ Lt.

\section{Uji Homogenitas}

Uji ini bertujuan untuk melihat apakah kedua sampel mempunyai varian yang homogen atau tidak. Adapun langkah-langkah uji homogenitas dua variasi adalah sebagai berikut (Sundayana, 2014).

1. Merumuskan hipotesis nol dan hipotesis alternatifnya:

$\mathrm{H}_{\mathrm{o}}$ : kedua varians homogen $\left(\mathrm{v}_{1}=\mathrm{v}_{2}\right)$

$\mathrm{H}_{\mathrm{a}}$ : kedua varians tidak homogeny $\left(\mathrm{v}_{1} \neq\right.$ $\mathrm{v}_{2}$ )

2. Menentukan nilai $F_{\text {hitung }}$ dengan rumus:

$\mathrm{F}_{\text {hitung }}=\frac{\text { variansbesar }}{\text { varianskecil }}=\frac{(\text { simpanganbakubesar })^{2}}{(\text { simpanganbakukecil })^{2}}$

3. Menentukan nilai $F_{\text {hitung }}$ dengan rumus:

Ftabel $=\mathrm{F}_{\alpha}\left(\mathrm{dk} \mathrm{n}_{\text {varians besar }}-1 / \mathrm{dk}_{\mathrm{k}} \mathrm{n}_{\text {varians }}\right.$ kecil-1)

4. Kriteria uji: jika $\mathrm{F}_{\text {hitung }}<\mathrm{F}_{\text {tabel }}$ maka Ho diterima (varians homogen)

\section{Uji t}

Uji $t$ ini dilakukan dengan menggunakan rumus uji t pada persamaan berikut (Sundayana, 2014).

$\mathrm{t}=\frac{X_{1}-X_{2}}{S \sqrt{\frac{1}{n_{1}}+\frac{1}{n_{2}}}}$

$S^{2}=\frac{\left(n_{1-1}\right) S_{1}^{2}+\left(n_{2-1}\right) S_{2}^{2}}{n_{1+} n_{2-2}}$

Hipotesis:

$H_{0}=\mu_{1}=\mu_{2}$ : Tidak ada pengaruh model pembelajaran Brain Based Learning terhadap keterampilan berpikir kritis.

$H_{1}=\mu_{1} \neq \mu_{2}$ : Terdapat pengaruh model pembelajaran Brain Based Learning terhadap keterampilan berpikir kritis.

\section{Uji N-Gain}

Gain adalah selisih antara nilai postest dan posttest.Gain menunjukkan peningkatan keterampilan berpikir kritis peserta didik setelah pembelajaran dilakukan guru. Untuk mengetahui peningkatan hasil belajar peserta didik digunakan rumus gain ternormalisasi menurut Hake (g) dalam Meltzer sebagai berikut(Sundayana, 2014).

$$
<g>=\frac{\text { Skorpostest }- \text { Skorpretest }}{\text { Skorideal }- \text { Skorpretest }}
$$

Tinggi rendahnya gain yang dinormalisasi (N-gain) dapat diklasifikasikan sebagai berikut. 
Tabel 2. Kategori Gain Ternormalisasi

\begin{tabular}{cc}
\hline $\begin{array}{c}\text { Nilai Gain } \\
\text { Ternormalisasi }\end{array}$ & Kategori \\
\hline$-1,00 \leq \mathrm{g}<0,00$ & Terjadi penurunan \\
$\mathrm{g}=0,00$ & Tidak terjadi peningkatan \\
$0,00<\mathrm{g}<0,30$ & Rendah \\
$0,30 \leq \mathrm{g}<0,70$ & Sedang \\
$0,70 \leq \mathrm{g} \leq 1,00$ & Tinggi \\
\hline
\end{tabular}

\section{Effect Size}

Effect Size dapatdihitungdenganformulasi dan dijabarkanlebihlebihrinci oleh Hake (Saregar, Latifah, \& Sari,2016). $d=\frac{m_{A}-m_{B}}{\left[\frac{\left(s d_{A}^{2}+s d_{B}^{2}\right)}{2}\right]^{1 / 2}}$

Tabel 3. Kategori Effect Size

\begin{tabular}{cc}
\hline Effect Size & Kategori \\
\hline $\mathrm{d}<0,2$ & Kecil \\
$0,2<\mathrm{d}<0,8$ & Sedang \\
$\mathrm{d}>0,8$ & Tinggi \\
\hline
\end{tabular}

\section{HASIL DAN PEMBAHASAN}

\section{Keterlaksanaan Model}

Pembelajaran Brain Based Learning (BBL)

Untuk mengetahui keterlaksanaan dari penggunaan model Brain Based Learning (BBL) dalam pembelajaran, maka dilakukan observasi aktivitas peneliti dan siswa selama proses pembelajaran berlangsung yang dibantu oleh observer.

Tabel 4. Tabel PersentaseKeterlaksanaan Model BBL Pada Lembar Observasi Kegiatan Pembelajaran Oleh Observer Terhadap Peneliti

\begin{tabular}{cc}
\hline Pertemuan ke- & Persentase \\
\hline 1 & $95 \%$ \\
2 & $97.5 \%$ \\
3 & $100 \%$ \\
\hline
\end{tabular}

Berdasarkan Hasil analisis observasi keterlaksanaan model oleh peneliti pada pertemuan pertama adalah sebesar $95 \%$, pertemuan kedua meningkat menjadi $97.5 \%$ dan pada pertemuan ketiga meningkat menjadi $100 \%$. Hal inimenunjukkan bahwa keterlaksanaan aktivitas peneliti sesuai dengan model BBL.
Tabel 5. Tabel PersentaseKeterlaksanaan Model BBL Pada Lembar Observasi Kegiatan Pembelajaran Aktivitas Siswa

\begin{tabular}{cc}
\hline Pertemuan ke- & Persentase \\
\hline 1 & $87.5 \%$ \\
2 & $75 \%$ \\
3 & $96.8 \%$ \\
\hline
\end{tabular}

Hasil analisis observasi keterlaksanaan model oleh siswa pada pertemuan pertama adalah sebesar $87.5 \%$, pertemuan kedua meningkat menjadi $75 \%$ dan pada pertemuan ketiga meningkat menjadi $96.8 \%$. Hal ini menunjukkan bahwa keterlaksanaan aktivitas siswa sesuai dengan model BBL.

\section{Peningkatan Keterampilan Berpikir Kritis}

Dari kegiatan pemberian perlakuan terhadap sampel berupa penggunaan model pembelajaran Brain Based Learning (BBL), peneliti mendapatkan data skor pretest dan postest keterampilan berpikir kritis. Berikut ini gambar 1 yang menunjukkan rekapitulasi skor rata-rata pretest dan postest keterampilan berpikir kritis kelas eksperimen dan kelas kontrol.

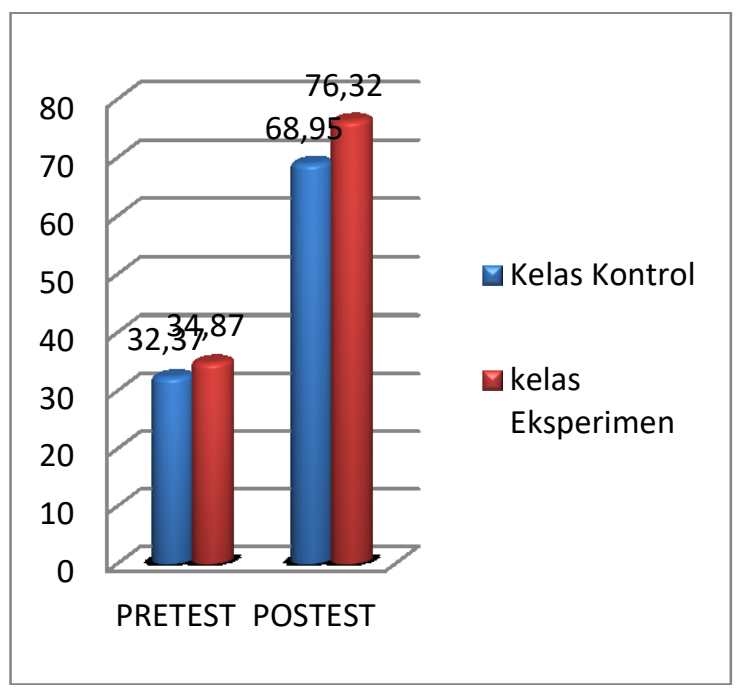

Gambar 1. Rata-rata Skor Prestes dan Postest

Berdasarkan gambar 1 terlihat bahwa rata-rata skor pretest dan postest kelas eksperimen lebih tinggi dibandingkan rata-rata skor pretest dan postest kelas kontrol. Hal ini menunjukkan bahwa 
penggunaan model pembelajaran $\mathrm{BBL}$ berpengaruh terhadap peningkatan keterampilan berpikir kritis siswa.

\section{Uji Normalitas}

Uji normalitas yang digunakan adalah uji Lilliefors, dari hasil pengujian keterampilan berpikir kritis untuk kelas eksperimen dan kelas kontrol dari hasil uji normalitas data tersebut dapat dilihat pada tabel 6 berikut.

Tabel 6. Hasil Uji Normalitas Pretest Data

\begin{tabular}{llccc}
\hline No & \multicolumn{1}{c}{ Kelas } & L $_{\text {hitung }}$ & $\mathbf{L}_{\text {tabel }}$ & Keputusan Uji \\
\hline 1 & Eksperimen (Model BBL) & 0,113 & 0,144 & $\mathrm{H}_{0}$ Diterima \\
2 & Kontrol (Konvensional) & 0,108 & 0,144 & $\mathrm{H}_{0}$ Diterima \\
\hline
\end{tabular}

Hasil uji normalitas data pengetahuan awal berpikir kritis terangkum dalam tabel diatas, tampak bahwa taraf signifikat 0,05 nilai $L_{\text {hitung }}$ untuk eksperimen 0,113 kurang dari $\mathrm{L}_{\text {tabel }}$ yaitu 0,144 sehingga hipotesis nol diterima jadi data pada kelas eksperimen normal, dan untuk kelas kontrol dengan taraf signifikan 0,05 nilai $\mathrm{L}_{\text {hitung }} 0,108$ kurang dari $\mathrm{L}_{\text {tabel }} 0,144$ sehingga hipotesis nol diterima. Dan dapat disimpulkan bahwa kedua kelas data pretest berdistribusi normal.

\section{Uji Homogenitas}

Uji homogenitas digunakan untuk mengetahui apakah beberapa varians populasi data sama atau tidak. Uji ini dilakukan sebagai prasyarat yang kedua dalam menentukan uji hipotesis yang akan digunakan. Uji homogenitas dilakukan data variabel terikat yaitu keterampilan berpikir kritis. Uji homogenitas ini membandingkan varians terbesar dan varians terkecil. Hasil uji homogenitas dengan taraf 0,05 diperoleh $\mathrm{F}_{\text {tabel }}$ yaitu 1,73 dan $\mathrm{F}_{\text {hitung }}$ yaitu 0,88 untuk kelas eksperimen dan kelas kontrol. Berdasarkan hasil perhitungan tersebut $\mathrm{F}_{\text {hitung }} \leq \mathrm{F}_{\text {tabel }}$ dengan demikian dapat diambil kesimpulan bahwa $\mathrm{H}_{0}$ diterima artinya bahwa populasi tersebut memiliki varians yang sama. Setelah diketahui data berasal dari populasi yang sama.

\section{Uji-t}

Pengujian dalam penelitian ini menggunakan Uji-t dua sampel tidak berkorelasi. Pengujian hipotesis dilakukan untuk menguji ada atau tidaknya perbedaan pengaruh beberapa perlakuan (penerapan model pembelajaran) terhadap keterampilan berpikir kritis peserta didik dapat dilihat pada tabel 7 berikut.

Tabel 7. Rekapitulasi Hasil Perhitungan Uji Hipotesis

\begin{tabular}{lrrrl}
\hline Kelompok & $\begin{array}{c}\text { Jumlah } \\
\text { Sampel }\end{array}$ & $\mathbf{T}_{\text {hitung }}$ & $\mathbf{T}_{\text {tabel }}$ & \multirow{2}{*}{ Keputusan Uji } \\
\cline { 2 - 4 } & 38 & 0,05 & 0,05 & \\
\hline $\begin{array}{l}\text { Eksperimen } \\
\text { Kontrol }\end{array}$ & 38 & 3,81 & 1,66 & \multirow{2}{*}{$\mathrm{H}_{0}$ Ditolak } \\
\hline
\end{tabular}

\section{Uji N-Gain}

Tabel 8. Hasil Pretest dan Postest Keterampilan Berpikir Kritis Siswa Kelas Eksperimen

\begin{tabular}{cccc}
\hline No & Komponen & Pretest & Postest \\
\hline 1 & Rata-rata & 34,87 & 76,24 \\
2 & Nilai tertinggi & 55 & 90 \\
3 & Nilai terendah & 15 & 65 \\
4 & Rata-rata $N$-Gain & $\mathbf{0 . 6 4}$ (sedang) \\
\hline
\end{tabular}

Untuk hasil nilai pretest dan postest peningkatan keterampilan berpikir kritis siswa kelas kontrol dapat dilihat pada tabel 9 berikut.

Tabel 9. Hasil Pretest dan Postest Keterampilan Berpikir Kritis SiswaKelas Kontrol

\begin{tabular}{cccc}
\hline No & Komponen & Pretest & Postest \\
\hline 1 & Rata-rata & 32,37 & 68,95 \\
2 & Nilai tertinggi & 55 & 85 \\
\hline
\end{tabular}




\begin{tabular}{cccc}
\hline 3 & Nilai terendah & 10 & 50 \\
4 & Rata-rata $N-$ & $\mathbf{0 . 5 5}$ (sedang) \\
& Gain & \\
\hline
\end{tabular}

\section{Effect Size}

Untuk mengetahui pengaruh pembelajaran Brain Based Learning (BBL) terhadap keterampilan berpikir kritis siswa menggunakan rumus effect size. Perolehan effect size dapat dilihat pada tabel 10 berikut.

Tabel 10. Hasil Effect Size

\begin{tabular}{lcccc}
\hline \multicolumn{1}{c}{ Kelas } & Rata-ratagain $(\mathbf{M})$ & Standar deviasi & Effect size & Keterangan \\
\hline Eksperimen & 41,3 & 9,2 & 0,586 & Sedang \\
kontrol & 36,5 & 7,0 & & \\
\hline
\end{tabular}

Setelah dilakukan pengolahan data dan analisis data hasil penelitian maka dapat diketahui keterampilan berpikir kritis peserta didik dapat dilihat dari nilai Pretest dan Posttest.Setelah dilakukan pengolahan dan analisis data hasil penelitian maka dapat diketahui keterampilan berpikir kritis peserta didik dapat dilihat dari nilai Pretest dan Posttest. Pretest diberikan diawal pertemuan sebelum diberikan perlakukan pada materi fluida statis. Dari data hasil penelitian kelas eksperimen terdapat nilai Pretest terendah 15 dan nilai tertinggi 65 dengan rata-rata 34,87 Sedangkan nilai Pretest pada kelas kontrol terdapat nilai terendah 10 dan nilai tertinggi 50 dengan rata-rata 32,37 Dilihat dari nilai rata-rata Pretest baik kelas eksperimen maupun kelas kontrol, maka keterampilan berpikir kritis peserta didik masih rendah, dan pada kedua kelas mempunyai keterampilan awal yang sama mengenai metari fluida statis.

Pada akhir pembelajaran diberikan Posttest. Nilai Posttest mengalami peningkatan baik pada kelas eksperimen maupun kelas kontrol. Nilai Posttest pada kelas eksperimen terdapat nilai terendah 55 dan nilai tertinggi 95 dengan nilai ratarata 76,24. Sedangkan nilai Posttest kelas kontrol terdapat nilai terendah 50 dan nilai tertinggi 85 dengan nilai rata-rata 68,95. Dilihat dari nilai rata-rata Posttest baik kelas eksperimen maupun kelas kontrol, maka keterampilan berpikir kritis peserta didik mengalami peningkatan.
Perbedaan yang signifikan antara peserta didik yang mengikuti pembelajaran dengan menggunakan model pembelajaran BBL dan peserta didik yang mengikuti pembelajaran dengan model konvensional disebabkan karena adanya perbedaan perlakuan pada langkah-langkah pembelajaran. Model pembelajaran BBL merupakan model pembelajaran yang disesuaikan dengan cara otak secara alamiah belajar. Proses pembelajaran yang dimaksud adalah proses pembelajaran yang menggunakan berbagai tahapan yang memudahkan otak untuk menangkap informasi dengan baik secara alamiah.

Tahapan pembelajaran yang dilaksanakan dengan menghubungkan peristiwa dalam kehidupan sehari-hari yang berkaitan dengan materi fluida statis, serta komunikasi yang terjalin dengan baik antara peneliti dengan siswa maupun siswa dengan siswa yang lain dapat tercipta suasana belajar yang kondusif sehingga siswa dapat menangkap informasi dengan baik. Selain itu peneliti hanya bertindak sebagai fasilitator dan memberikan kesempatan kepada peserta didik terlibat langsung dalam proses pembelajaran yang berlangsung.

Hasil penelitian ini membuktikan bahwa pembelajaran dengan model BBL dan disesuaikan dengan materi yang diajarkan dapat memberikan keterampilan berpikir kritis siswa yang lebih baik daripada pembelajaran yang menggunakan pembelajaran konvensional. 


\section{KESIMPULAN}

Berdasarkan

hasil analisis, pengolahan data dan pembahasan maka peneliti dapat menarik kesimpulan bahwa penerapan model pembelajaran Brain Based Learning (BBL) memberikan pengaruh terhadap peningkatan keterampilan berpikir kritis peserta didik pada pokok bahasan fluida statis. Hal ini terlihat dari nilai rata-rata hasil tes keterampilan berpikir kritis peserta didik dengan model pembelajaran Brain Based Learning (BBL) lebih tinggi dari rata-rata hasil tes keterampilan berpikir kritis peserta didik dengan menggunakan model konvensional. Dengan demikian penerapan model pembelajaran Brain Based Learning (BBL) sangat membantu dalam proses kegiatan belajar mengajar fisika agar peserta didik lebih aktif sehingga pembelajaran akan lebih efektif dan efesien.

\section{DAFTAR PUSTAKA}

Arikunto, S. (2014). Prosedur Penelitian Suatu Pendekatan Praktik. Jakarta: Rineka Cipta.

Diani, R., Latifah, S., Anggraeni, Y. M., \& Fujiani, D. (2018). Physics Learning Based on Virtual Laboratory to Remediate Misconception in Fluid Material. Tadris: Jurnal Keguruan Dan Ilmu Tarbiyah, 3(2).

Ihsan, F. (2011). Dasar Dasar Kependidikan. Jakarta: Rineka Cipta.

Isro'i, N. F., \& Ghufron, A. (2015). Keefektifan Metode Brain-Based Learning Terhadap Motivasi dan Prestasi Belajar Siswa Pada Mata Pelajaran Matematika. Jurnal Inovasi Teknologi Pendidikan, 2(1).

Laksmi, P. K., Sujana, I. W., \& Suryaabadi, I. B. G. (2014). Pengaruh Model Pembelajaran Berbasis Otak (Brain Based Learning) Berbantuan Media Teka Teki Silang Terhadap Hasil Belajar IPS Siswa Kelas V SD Gugus I Gusti
Ngurah Jelantik. Jurnal Mimbar PGSD Universitas Pendidikan Ganesha, 2(1).

Lestari, K. E. (2014). Implementasi Brain-Based Learning Untuk Meningkatkan Kemampuan Koneksi Dan Kemampuan Berpikir Kritis Serta Motivasi Belajar SISWA smp. Jurnal Pendidikan Unsika, 2(1).

Mustiada, I. G. A. M., Agung, A. A. G., \& Antari, N. N. M. (2014). Pengaruh Model Pembelajaran BBL ( Brain Based Learning ) Bermuatan Karakter Terhadap Hasil Belajar Ipa. Jurnal Mimbar PGSD Universitas Pendidikan Ganesha, 2(1).

Nur, I. R. D. (2016). Meningkatkan Kemampuan Berpikir Kreatif Matematis dan Kemandirian Belajar Siswa dengan Menggunakan Model Pembelajaran Brain Based Learning. Jurnal Pendidikan Unsika, 4(1).

Pratiwi, T. R., \& Muslim. (2016). Using Integrated Type On Science Learning For Improving Junior High School Student's Critical Thinking Skills. Jurnal Pendidikan Fisika Indonesia, 12(1).

Saregar, A., Irwandani, Abdurrahman, Parmin, Septiana, S., Diani, R., \& Sagala, R. (2018). Temperature and Heat Learning Through SSCS Model with Scaffolding: Impact on Students ' Critical Thinking Ability. Journal for the Education of Gifted Young, 6(3).

Saregar, A., Latifah, S., \& Sari, M. (2016). Efektivitas Model Pembelajaran CUPS: Dampak Terhadap Kemampuan Berpikir Tingkat Tinggi Peserta Didik Madrasah Aliyah Mathla'ul Anwar Gisting Lampung. Jurnal Ilmiah Pendidikan Fisika Al-BiRuNi, 5(2).

Sundayana, R. (2014). Stastika Penelitian Pendidikan. Bandung: Alfabeta.

Wati, W., \& Fatimah, R. (2016). Effect Size Model Pembelajaran Kooperatif Tipe Number Heads Together (NHT) 
Terhadap Kemampuan Berpikir

Kritis Siswa Pada Pembelajaran

Fisika. Jurnal Ilmiah Pendidikan

Fisika Al-BiRuNi, 5(2). 